\title{
Civil-Military Relations in Europe, the Middle East and Turkey
}

\section{Nil S. Satana}

To cite this article: Nil S. Satana (2011) Civil-Military Relations in Europe, the Middle East and Turkey, Turkish Studies, 12:2, 279-292, DOI: 10.1080/14683849.2011.572634

To link to this article: http://dx.doi.org/10.1080/14683849.2011.572634

$$
\text { 曲 Published online: } 01 \text { Jul } 2011 .
$$

Submit your article to this journal $[\pi$

LII Article views: 713

Q View related articles $₫$

Citing articles: 3 View citing articles ए 


\title{
Civil-Military Relations in Europe, the Middle East and Turkey
}

\author{
NIL S. SATANA \\ Department of International Relations, Bilkent University
}

\begin{abstract}
This article seeks to understand the transformation of Turkish civil-military relations in a comparative perspective. The analysis is based on two criteria: institutional/ legal mechanisms and political oversight of the military's autonomy. Comparison of European and Middle Eastern civil-military relations models to the Turkish paradigm unveils grave differences between Turkish and Middle Eastern civil-military relations. The Turkish model in transformation for at least a decade is closer to the European model in both legal and political aspects. Nevertheless, the article underscores that Turkish civil-military relations are still in transformation and although the EU accession process has gradually democratized the legal system of the country, democratic consolidation requires further advances in the political domain. Consequently, consolidation in Turkey depends not only on retreating of the military from the political realm but also on the proper civilianization of the regime in theory and practice.
\end{abstract}

\section{Introduction}

In 1993, long before the latest debates on the shift of Turkey's axis in foreign policymaking, Graham Fuller depicted Turkey's general orientation as Eastern and not Western. ${ }^{1}$ Later, in 2005, as a presidential candidate of France, Nicolas Sarkozy compared Turkey with Lebanon and asserted that Lebanon owns more European values than Turkey. Sarkozy described Turkey as an "Asian country," and objected to Turkey's accession to the European Union (EU). ${ }^{2}$ On the contrary, former German Chancellor Gerhard Schroder and former British Prime Minister Tony Blair did not question Turkey's "Europeanness" and instead supported Turkey's bid for the EU membership.

Likewise, several Western scholars have had contrasting perceptions of Turkey, classifying the country as an authoritarian state in the Middle East. For example, Tim Jacoby has argued that Turkey's regime structure has been far from democratic since Turkey has adopted a semi-authoritarian incorporation strategy in the 1960s and 1970 s while an autocratic militarism followed as a state strategy after the 1980 coup. $^{3}$

Correspondence Address: Nil S. Satana, Department of International Relations, Bilkent University, 06800 Bilkent, Ankara, Turkey. Email: nsatana@bilkent.edu.tr. 
In his 2003 article, Jacoby has pointed to the longevity of military involvement in Middle Eastern politics by using Turkey as a case in point. Jacoby has not referred to any positive transformations taking place in the last couple of decades in civilmilitary relations in Turkey. Along the same lines, Linda Michaud-Emin examined the effect of the EU harmonization packages on Turkish civil-military relations (CMR) and she found little change in Turkish civil-military relations even after the recent reforms. Thus, according to her, inefficiency and instability of the Turkish political system lingers on. ${ }^{4}$

In a comparative study, Steven Cook situates Turkish CMR in the Middle Eastern civil-military relations paradigm, arguing while "Turks often chafe at the suggestion, the processes and patterns that characterized the Turkish political system until the early 2000s resembled those in Egypt and Algeria." ${ }^{5}$ Cook compares three predominantly Muslim countries, Algeria, Egypt and Turkey, to examine how institutional settings under the legacy of military domination lead to the endurance of authoritarianism in the Middle East. In essence, Cook tries to figure out how the military achieves ruling without having to govern. In sum, since all three cases are portrayed as authoritarian states with strong militaries, Cook does not find the comparison of Turkey, Egypt and Algeria within the same framework problematic. ${ }^{6}$

While comparisons of the Turkish CMR to the Middle Eastern paradigm are scarce, studies that compare the Turkish case to the European norms and standards are abundant. Although most studies on Turkish civil-military relations have used the single case study method to advance theoretical or empirical arguments for explaining the political power of the Turkish military, ${ }^{7}$ comparative studies of Turkish CMR have considered Turkey among democracies such as those of the EU members and Israel. ${ }^{8}$ Anthony Forster, for example, includes Turkey in his comparative study of armed forces in Europe as a country that is gradually transforming its CMR for the EU membership. ${ }^{9}$ Along the same lines, Özkan and Tsarouhas highlight the importance of the EU accession process in the civilianization of Greece and point to the possible impacts of the EU accession process on further democratization of Turkey. ${ }^{10}$ Karabelias in turn includes Turkey in a comparison of southeastern European countries together with Albania and Greece in terms of the size of the military, its ideology, political culture/institutions and external factors. ${ }^{11}$ Karabelias suggests that each country follows its own path to achieve liberal democratic standards so that they can become members of the EU. Turkey, according to Karabelias, is fortunate since its political culture and leadership were already transforming, even before the pressure of the EU has led to several additional reforms to enhance Turkey's democratization. ${ }^{12}$

Others too highlight the importance of reforms leading to the evolution of the CMR in Turkey in a liberal direction. For example, $\mathrm{Cizre}^{13}$ and Misrahi ${ }^{14}$ point to the significance of change in the nature of Turkish civil-military relations in the last few decades. Narlı's work also places Turkey in the southern European military culture and underscores the evolution of civil-military relations in the country. ${ }^{15}$

Still other studies compare the Turkish military to Latin American militaries. Some of those studies also see the CMR in Turkey moving toward the liberal model. In their 
work that compares Turkey with Latin America in terms of democratic consolidation and transformation of their militaries, Heper and Güney emphasize the progress in Turkish CMR. ${ }^{16}$ David Pion-Berlin in this volume makes a similar assessment. ${ }^{17}$

This article compares the Turkish civil-military relations to the Western European, Eastern European, and Middle Eastern CMR. In each case, the analysis is based on political and legal aspects of civil-military relations.

\section{Western European versus Turkish Civil-Military Relations ${ }^{18}$}

Most scholars underline the absence of a unified and formal European framework of civil-military relations and, rather, point to the best practices. ${ }^{19}$ As Volten and Drent posit, "there is no such thing as one single European practice." ${ }^{20}$ Democracy in European states is built on several different formal and informal rules with each state gradually developing its own system of democratic supervision over the military. Although there are concerns about whether the development of a European Security and Defense Policy (ESDP) will jeopardize civilian control of security policies in the $\mathrm{EU},{ }^{21}$ it has been concluded that member states manage to "balance between civilian direction and ... recognition of military professionalism in their diverse defense policies." 22

Here the differences and similarities between the Turkish CMR and the Western European model will be taken up in terms of two interrelated criteria: legal/ institutional mechanisms and political oversight of the military's autonomy. ${ }^{23}$ In the European paradigm, different legal and institutional mechanisms lead to different practices in CMR. For example, in most European states, the role of the Commander in Chief of the Armed Forces is assigned to the head of the state or the government. ${ }^{24}$ However, in Germany, the Commander in Chief is the Federal Minister of Defense and not the Prime Minister. ${ }^{25}$ However, the duties, rights and responsibilities of both the civilians and the military are ascertained in Western Europe in a liberal direction and both sides conform to them.

Another significant legal/institutional aspect of civil-military relations in Europe is related to the presence of an integrated Ministry of Defense, which supervises the Office of the General Staff and holds that office responsible to the Minister of Defense that in turn is responsible to the government for "the management of the armed forces, formulation and conduct of defense policies, and territorial defense of the country, as well as development of long-term political-military goals." ${ }^{26}$ It is true that in different European countries, the Chief of the General Staff is responsible to the Prime Minister, President or the Minister of Defense depending on the institutional structure of the state determined by each state's needs and past experiences. Nevertheless, in all cases the Chief of the General Staff is legally and institutionally bound to civilian authorities and they act in that manner.

The second criterion, political oversight of the military's autonomy in policymaking, on the other hand, is intertwined with institutional/legal set-up of civilmilitary relations. In parliamentary/prime ministerial European systems such as Denmark, Slovenia, Sweden and the UK, the head of the state is not the same as 
the head of the government. ${ }^{27}$ While the head of the state is the Commander-in-Chief of the Armed Forces, "his/her authority is mostly symbolic in nature, and in practice the head of the government is responsible to the parliament for defense of the country and control of the armed forces." ${ }^{28}$ Thus, in these systems, political oversight is rather strong as the final decision-making power rests in the cabinet or the minister, the latter being accountable to the parliament. ${ }^{29}$ In other words, the institutional set-up guarantees the adequate political control of the military by empowering the civilians over the office of the General Staff.

In presidential and semi-presidential European systems such as Bulgaria, Finland, Poland and Romania, an elected President is the supreme commander, who supervises the Minister of Defense. In these countries, although the Chief of the General Staff is legally responsible to the Minister of Defense, s/he has a more direct access to the President than the Minister. According to Volten and Drent, a weak coalition government or competition between the prime minister and the president renders presidential and semi-presidential systems weaker than parliamentary systems in terms of civil-military relations. ${ }^{30}$ Put differently, political oversight of the military is at times a one-man job rather than a collective civilian task in presidential and semi-presidential systems such as in France.

France is worth further examination since it is an outlier among many European cases in terms of civil-military relations. In the French semi-presidential system, the President is the ultimate decision-maker in important security and defense institutions such as the Defense and National Security Council. Moreover, co-habitation has been especially problematic in France for formulating and implementing defense policies. The CMR in France, in other words, has been traditionally conflict-ridden.

In contrast, a closer examination of the UK shows that the head of the state, the Monarch, is the Commander in Chief; however, it is really the Monarch's government that plays an important role in defense policy-making. Institutionally, the Prime Minister, as the head of the government, is the supreme decision-maker in civil-military relations. ${ }^{31}$ The Chief of the General Staff has direct access to the Prime Minister. ${ }^{32}$ It is true that on paper the Ministry of Defense, answerable to both the Parliament and the Prime Minister, is the primary institution responsible for the formulation and conduct of defense policies, ${ }^{33}$ and the General Staff is responsible to the Minister of Defense. However, the Prime Minister and the cabinet have close ties to the office of the General Staff, and it is for this reason that the Prime Minister and his cabinet together are the final decision-makers in important military matters. ${ }^{34}$ In the UK, both institutionally and politically, civilians in different levels supervise the military.

The Turkish case with its parliamentary political system resembles both presidential and parliamentary systems in terms of its institutional/legal set-up of CMR. In line with European parliamentary systems, Turkey's head of the government (Prime Minister) is distinct from the head of the state (President). The Turkish General Staff has direct access to the Prime Minister and the President, through formal and informal meetings ${ }^{35}$ or through the National Security Council (NSC) meetings every other month. Following a common pattern with semi-presidential 
and presidential systems in Europe, according to Article 118 of the Constitution, "the agenda of the National Security Council shall be drawn up by the President of the Republic taking into account the proposals of the Prime Minister and the Chief of the General Staff."

The President is the Commander in Chief, and has the authority to determine the use of the armed forces and send troops abroad upon the approval of the parliament. Nevertheless, in contrast to the situation in France, these powers are not actively used. Unlike the French President, the President in Turkey has only an intermediary role in civil-military relations; he mediates between the government and the military, i.e. in the NSC meetings. On the other hand, the Turkish institutional set-up including the NSC is similar to the new Defense and National Security Council established in France in 2008 by the "French white paper on defense and national security." 36

Similarities between Turkish and European institutional/legal systems are numerous due to Turkey's aspirations for the EU membership; however, the major difference between the EU and Turkish institutional mechanisms is the structure of the Ministry of National Defense. This is at the same time the most often pronounced issue by the EU regarding the civil-military relations in that country. ${ }^{37}$ In Turkey, the Minister of National Defense is responsible to the Prime Minister, and the Office of the General Staff is not incorporated into the Ministry of Defense. While the two cooperate as ruled by Law No. 1325 on the Duties and Organization of the Ministry of National Defense, the Turkish Armed Forces is accountable directly to the Prime Minister. ${ }^{38}$ This situation is rooted in the historical remnants of military interventions. The General Staff was constitutionally and politically responsible to the Ministry of National Defense before the 1960 military coup. Following the intervention, the military argued that the Democrat Party governments (1950-1960) had tried to manipulate the armed forces for political gains by using the Ministry of National Defense. Thus, detaching the Office of the General Staff from the Ministry of National Defense in 1961 and 1982 Constitutions transformed the organizational structure of civil-military relations. The Minister of Defense came to have hardly any political control over the Chief of the General Staff due to this institutional design.

The second issue that brings criticism to Turkish CMR is rather weak political oversight of the military's autonomy. Turkish politicians, until recently, have mostly yielded to the military's guardianship role. While demilitarization has been an ongoing process for decades, civilianization of politics has been limited. ${ }^{39}$ One aspect of political oversight is related to how much the parliament is involved in defense policy-making. While especially the Dutch have been praised for their very strict parliamentary control of defense policies, the Turkish parliament has not been as active.

It should be noted here that the European practice is not uniform in this domain either. For example, while political oversight of defense policy decisions is strict in Germany, it clearly is not in France. The French parliament "will be informed as he [President] wishes, [and] even if the people's representative takes the trouble of demanding direct involvement in the security policy," the president may or may not involve the parliament in the process. $" 40$ Therefore, in terms of political oversight 
of the military by the parliament, the Turkish system resembles the French but not the German or Dutch systems, which are more transparent.

In sum, the main discrepancies between Turkey and the EU countries stems from the absence of an integrated Defense Ministry where the General Staff is responsible to the Minister of National Defense in addition to limited political control of defense policy-making by civilian organs such as the parliament. While the former is still an ongoing debate, on the latter issue some progress was made in recent years concerning the control of the parliament over the military expenditures. ${ }^{41}$

While these two differences remain, as mentioned earlier, the Turkish system is similar to the French in some ways and to the British and German in others. For example, according to Klaus-Jürgen Müller, in the past both French and German militaries have at times intervened in politics as the Turkish military did, since those armed forces had also regarded themselves as the savior of the nation and the state. ${ }^{42}$ Moreover, both French and German militaries, like their Turkish counterpart, compromised their reputations by getting drawn into politics by the civilians ${ }^{43}$ until a common democratic practice in Europe has become the norm, especially after the 1990s. Likewise, despite its differences, with the help of institutional and political changes undertaken for EU accession, Turkish civil-military relations may further converge with the Western European model in the years to come.

\section{Central and Eastern European versus Turkish Civil-Military Relations}

The Central and East European (CEE) countries have generally followed a different course than the Western civil-military relations due to their communist heritage. According to Stefan Sarvas, the post-communist CEE governments legitimated themselves using the "constitutional framework, political supervision and public's acceptance." 44 In his 1999 article, Sarvas argues that democratization had been under way in Bulgaria, the Czech Republic, Hungary, Poland, Romania, Slovakia and Slovenia, although the military was often involved in politics. ${ }^{45}$ In those states that had a stricter communist legacy where the military's major role was to support the Party in maintaining the Communist regime (i.e. Czechoslovakia, Bulgaria and Romania), the military was an ordinary actor in politics. ${ }^{46}$ Once the Cold War came to an end, although institutional mechanisms changed and the military has become legally separated from politics through banning of military officers from participating in political parties, political oversight of the military in post-communist CEE countries has been a key challenge. Sarvas emphasizes the effect of the NATO expansion as a vehicle for increasing democratic control in post-communist countries at the end of the 1990s. ${ }^{47}$

Jones and Mychajlyszyn also point to the effect of NATO on the democratization of civil-military relations as an actor that pushes for both institutional and political reforms in post-communist states. ${ }^{48}$ While Serbia and Croatia are assessed as countries with weak civilian control, the Russian Federation is under the heavy control of Putin; thus, the military is still the defender of the regime/party. In these countries, the Minister of Defense is generally not a civilian, and except for 
Poland, Hungary and the Czech Republic, political oversight of the military by civilians is insubstantial. ${ }^{49}$

Once again parliamentary versus semi-presidential and presidential institutional design makes a difference for political oversight of the military. According to Zoltan Barany, in parliamentary systems such as Hungary, the Czech Republic and Slovakia, a stable and balanced civilian control of the military was quite successful since the power of the President was only symbolic. ${ }^{50}$ However, in presidential systems such as Romania and Poland, the chief executive was very powerful, and in both cases the presidential system was established to strengthen the hands of the old elite. ${ }^{51}$ Thus, in Romania and Poland, the parliament was in a weaker status vis-à-vis the military. These choices of institutional/legal mechanisms, in turn, affected civilian control of the military and the armed forces' domestic political role in the CEE civil-military relations. ${ }^{52}$

The Turkish case is different from the CEE civil-military relations. The legacy of communism and the strong Communist Party tradition have led to either professional or politicized militaries in the CEE states. Some CEE countries transformed into more liberal and democratic states while others were hardly depoliticized and the militaries such as the Romanian armed forces have often been used for domestic situations. ${ }^{53}$ Despite these dissimilarities, Turkish and CEE civil-military relations share one focal common trait: the impetus of external factors for democratization. What the EU has so far accomplished in terms of Turkey's democratic consolidation has been matched by first the effect of NATO on civil-military relations of CEE countries and later by the EU enlargement process through which some of the CEE countries were integrated in the EU, in 2004 and 2007, respectively. Starting from very different backgrounds due to historical and institutional legacies, these cases have converged in a process of political oversight of the military because of their drive for being a part of Western institutions such as NATO and the EU.

\section{Middle Eastern versus Turkish Civil-Military Relations ${ }^{\mathbf{5 4}}$}

Although militaries in the Middle East are strongly connected to the political regimes of their states, there is still limited recent work on Middle Eastern civil-military relations. ${ }^{55}$ Majid Khadduri's seminal work on the Middle East published in 1953 refers to an Islamist ideologist, Sayyid Jamal al Din, who once argued that only a dictator can rule in the Middle East. ${ }^{56}$ In contrast, Khadduri posits that Kemal Atatürk left behind his military duties and set up a parliamentary system of government while his contemporaries in the Middle East failed to achieve similar progress. ${ }^{57}$ This was due to "an almost nostalgic longing in the Middle East, common to all political groups, for a strong regime which will tolerate neither multiplicity of political parties nor anarchy of ideas." 58 Thus, the civilians and the military in that region did not have trust for democracy, which was "transplanted into a social milieu unprepared for it." ${ }^{59}$ Thus, the institutional/legal mechanisms in the Middle East were based either on an Islamic religious order (Sharia), or on personal dictatorships and monarchies. 
In contrast, after the proclamation of the new Republic in 1923, the Turkish military was a strong believer in Westernization, this was also the ultimate goal of the Kemalist Turkish Armed Forces. In other words, while modernization was a foreign concept to most Middle Eastern states after the end of the colonization era, the Turkish military pioneered modernization in Turkey ever since the last decades of the Ottoman Empire. ${ }^{60}$ As a result, the Turkish political regime became first a parliamentary system (1923) and later a multi-party system (1945). In other words, the Turkish legal/institutional set-up was significantly different from its Middle Eastern counterparts.

Another difference in this early period between the Turkish case and Middle Eastern CMR is that the latter's coup d'états were mostly a result of losing wars, hence punishing politicians for their incompetence at war times, ${ }^{61}$ while the former intervened to topple governments, which either had authoritarian tendencies or were unable to curb the violence on the streets. Since the modern Turkish military has never lost a war, it has constructed a national identity on the bravery of the Turkish nation. Moreover, while the military in Middle Eastern states was a stepping-stone for high governmental office, this was not the case for the Turkish military in the early Republican era. ${ }^{62}$ Upon Atatürk's direction, the 1924 Constitution ruled that officers resigned before they could get involved in politics. ${ }^{63}$ Almost two decades later, in James Bill's 1969 comparison of Egypt, Iran, Iraq and Syria, Middle Eastern armies were deemed "continually rent by internal cleavage and conflict." ${ }^{64}$ In contrast, Turkey was shown as having a cohesive military, which is different from the others for its long-term modernizing role. In Bill's four other cases, militaries switched roles from coup to coup, from a "modernizing" role to "protecting the status quo." Iraq, for example, experienced seven coups in five years (1936-41). ${ }^{65}$

Several decades after James Bill's analysis, Mehran Kamrava has argued that the Huntingtonian military professionalism ${ }^{66}$ has seldom led to political civilianization in the Middle East. Instead, it often triggered military interventions. ${ }^{67}$ Accordingly, the political role of the military follows a similar pattern in all Middle Eastern countries. However, Kamrava highlights the concept of democratization so that Turkey is compared to Israel while Algeria, Egypt, Sudan, Syria, Tunisia and Yemen are compared to one another. According to Kamrava, except for Israel and Turkey, the role of the military in all Middle Eastern and North African states is overt. Kamrava's argument implies that the democratic regime structure adopted in Turkey increases the political oversight of the military's autonomy while the same is not possible in authoritarian institutional/legal systems of Middle Eastern countries.

In a similar vein, David Sorenson compares Algeria to other North African countries and conceptually distinguishes between military as "another player" and as "a dominating actor." In Turkey the military is "another player" while in Algeria, Morocco, Tunisia and Libya the military is "a dominating actor.",68 Along the same lines, in Kamrava's study, Israel and Turkey are included as "ostensibly democratic states," Iran, Iraq and Libya as inclusionary states with militaries kept in check by volunteer militias, and Algeria, Egypt, Syria, Sudan, Tunisia and Yemen as exclusionary states where non-ideological civilian autocrats rule. 
Finally, Jordan, Kuwait, Morocco and Saudi Arabia are illustrated as countries where tribal loyalty is used to counterbalance the political and economic autonomy of the military. ${ }^{69}$

The final important difference between the Turkish military and Middle Eastern militaries is the presence of multiple military branches in the latter. ${ }^{70}$ Although there are recent differences of opinion within the Turkish military, compared to its Middle Eastern counterparts, the Turkish Armed Forces has been quite cohesive. The interventions after 1960 have not significantly altered the chain of command in Turkey, while, for example, in Iran, the Islamic Revolutionary Guard Corps established by direct order from Khomeini in May 1979 coexists with the Basij militia, which was formed to suppress anti-revolutionaries in $1979 .{ }^{71}$

While there are overwhelming differences between Middle Eastern civil-military relations and the Turkish case, only a most suspicious eye can find a similarity between Turkish and Middle Eastern civil-military cases. One such similarity can be the nature of threats that the military perceives in the internal political scene. While the Turkish military has been wary of Kurdish separatism and Islamist fundamentalism, Algeria, for example, has had similar concerns about religious fundamentalism. ${ }^{72}$ These perceptions of threat at times led to interventions in both Turkey and Middle Eastern countries. Thus, despite institutional differences, certain military perceptions on what constitutes a threat to the regime have led to the similar consequence of overt military interventions in both cases. Nevertheless, it would be fair to say that the Middle Eastern civil-military relations paradigm has more differences than similarities with Turkish CMR in terms of the two criteria used in this article to compare cases-institutional/legal mechanisms and political oversight of the military's autonomy.

\section{Conclusion: Turkish Civil-Military Relations in between Paradigms?}

Institutional/legal mechanisms in Turkey are closer to European civil-military relations models than the Middle Eastern (and North African) CMR paradigm. According to Linz and Stepan, "democratic transition is complete when a government elected by free and popular vote has the authority to make policies and all parties accept the democratic nature of the regime." ${ }^{, 73}$ Consolidation, on the other hand, emerges behaviorally, attitudinally, and constitutionally when all actors in the political regime genuinely accept democracy as the best form of government. Accordingly, the conceptualization of democratization as a process situates the Turkish case closer to the categories of Western European advanced democracies and Central and Eastern European developing democracies, and further from the Middle Eastern civil-military relations category.

Institutional/legal mechanisms are dynamic and civil-military relations transform over time. The Turkish case indicates that constitutional and attitudinal dimensions of democratization have been long under way and Turkey has been struggling through behavioral change in trying to fully civilianize its civil-military relations ${ }^{74}$ In contrast, the role of the military in Middle Eastern countries has been relatively static 
and mostly against modernization attempts ${ }^{75}$ while the Turkish military has been transforming due to several factors, including the changes in military mindset ${ }^{76}$ and the impact of the European Union. ${ }^{77}$

In terms of political oversight of the military, the Turkish case has been gradually transforming in conjunction with institutional/legal reforms. The Turkish military is less out-spoken and increasingly realizes that it is subordinate to civilian authorities. ${ }^{78}$ The civilians are now less submissive to military direction of politics and parliamentarians are relatively more interested in defense policy-making and in controlling the defense budget. Parallel to recent debates on its role, the military seems to be cautiously retreating from the political domain. In fact, the $2010 \mathrm{EU}$ progress report has pointed to positive developments in Turkish CMR. ${ }^{79}$ While civil-military relations transform in the country, it is yet unclear whether Turkish democracy is sufficiently civilianized to complete democratic consolidation.

In sum, the juxtaposition of Turkish, Western and Central and Eastern European and Middle Eastern civil-military relations paradigms shows that the Turkish case draws parallels to the European paradigm more than the Middle Eastern model. Differences between European and Turkish civil-military relations will, to a great extent, be curbed when/if an integrated Ministry of Defense is established and as civilians further increase the political oversight of the military. There is little doubt that a complete convergence with the European civil-military relations paradigm is the key to Turkey's bid for EU membership.

\section{Notes}

1. Graham E. Fuller, "Turkey's New Eastern Orientation," in Graham E. Fuller and Ian O. Lesser, Turkey's New Geopolitics: From the Balkans to Western China (Boulder, CO: Westview/RAND, 1993).

2. "French Minister Sarkozy Declares 'War' Against Turkey’s EU Membership," (2006), http://www. turkishweekly.net/news/38109/french-minister-sarkozy-declares-war-against-turkey-s-eumembership.html

3. Tim Jacoby, "For the People, Of the People and By the Military: The Regime Structure of Modern Turkey," Political Studies, Vol. 51, No. 4 (2003), pp. 669-85.

4. Linda Michaud-Emin, "The Restructuring of the Military High Command in the Seventh Harmonization Package and its Ramifications for Civil-Military Relations in Turkey," Turkish Studies, Vol. 8, No. 1 (2007), pp. 25-42.

5. Steven A. Cook, Ruling But Not Governing: The Military and Political Development in Egypt, Algeria, and Turkey (Baltimore, MD: Johns Hopkins University Press, 2007), p. 12.

6. For a more detailed analysis of Cook's argument: Nil S. Satana, "Book Review: Cook, S. A. (2007). Ruling But Not Governing: The Military and Political Development in Egypt, Algeria, and Turkey," Armed Forces and Society, Vol. 37, No. 1 (January 2011), pp. 195-9.

7. The single case studies on Turkey include the following: Daniel Lerner and Richard D. Robinson, "Swords and Ploughshares: The Turkish Army as a Modernizing Force," World Politics, Vol. 13, No. 1 (1960), pp. 19-44; George S. Harris, "The Causes of the 1960 Revolution in Turkey," Middle East Journal, Vol. 24, No. 4 (Autumn 1970), pp. 438-54; Ümit Cizre Sakallığlu, "The Anatomy of the Turkish Military's Political Autonomy," Comparative Politics, Vol. 29, No. 2 (1997), pp. 151-6; Gareth Jenkins, Context and Circumstance: the Turkish Military and Politics (Oxford; New York: Oxford University Press for the International Institute for Strategic Studies, 
2001); Tanel Demirel, "Civil-Military Relations in Turkey: Two Patterns of Civilian Behavior Towards the Military," Turkish Studies, Vol. 4, No. 3 (Autumn 2003), pp. 12-17; Metin Heper, "Civil-Military Relations, Political Islam, and Security: The Turkish Case," in Civil Military Relations, Nation-Building, and National Identity: Comparative Perspectives, eds. C. P. Danopoulos, D. Vajpeyi, and A. Bar-O, Praeger: Westport, Connecticut and London, 2004; A. Kadir Varoğlu and Adnan Biçaksız, "Volunteering for Risk: The Culture of the Turkish Armed Forces," Armed Forces and Society, Vol. 31, No. 4 (Summer 2005), pp. 583-98; Metin Heper, "The Justice and Development Party Government and the Military in Turkey," Turkish Studies, Vol. 6, No. 2 (2005).

8. The comparative studies on Turkey include the following: Gerassimos Karabelias, "A Brief Overview of the Evolution of Civil-Military Relations in Albania, Greece, and Turkey during the Post WWII Period," Journal of Political and Military Sociology, Vol. 31, No. 1 (2003), pp. 57-70; Ümit Cizre, "Problems of Democratic Governance of Civil-military Relations in Turkey and the European Union Enlargement Zone," European Journal of Political Research, Vol. 43, No. 1 (January 2004), pp. 107-25; Tanel Demirel, "Lessons of Military Regimes and Democracy: The Turkish Case in a Comparative Perspective," Armed Forces and Society, Vol. 31, No. 2 (Winter 2005), pp. 245-71; Metin Heper and Joshua R. Itzkowitz-Shifrinson, "Civil-Military Relations in Israel and Turkey," Journal of Political and Military Sociology, Vol. 33, No. 2 (2005), pp. 23148; Dimitris Tsarouhas and Özkan Duman, “'Civilianization' in Greece vs. 'Demilitarization' in Turkey: A Comparative Study of the Civil-Military Relations and the Impact of the European Union," Armed Forces and Society, Vol. 32, No. 3 (2006), pp. 403-26; Nil S. Satana, "Transformation of the Turkish Military and the Path to Democracy," Armed Forces and Society, Vol. 34, No. 3 (2008), pp. 357-88.

9. Anthony Forster, Armed Forces and Society in Europe (New York: Palgrave Macmillan, 2006).

10. Nilüfer Narl1, "Civil-Military Relations in Turkey" in Phillip H. Fluri, Gustav E. Gustenau, Plamen I. Pantev (eds), The Evolution of Civil-Military Relations in South East Europe (Heidelberg: Physica-Verlag, 2005).

11. Gerassimos Karabelias, "The Evolution of Civil-Military Relations in Post-War Turkey, 1980-95," Middle Eastern Studies, Vol. 35, No. 4 (1999), p. 130.

12. Ibid.

13. Ümit Cizre, "Problems of Democratic Governance of Civil-Military Relations in Turkey and the European Union Enlargement Zone," European Journal of Political Research, Vol. 43, No. 1 (January 2004), pp. 107-25.

14. Frederic Misrahi, "The EU and the Civil Democratic Control of Armed Forces: An Analysis of Recent Developments in Turkey," Perspectives: Central European Review of International Affairs (2004), pp. $22-42$.

15. Narlı, "Civil-Military Relations in Turkey" (2005).

16. Metin Heper and Aylin Güney, "The Military and the Consolidation of Democracy: The Recent Turkish Experience," Armed Forces \& Society, Vol. 26, No. 4 (October 2000).

17. See David Pion-Berlin, "Turkish Civil-Military Relations: A Latin American Comparison," in this volume.

18. This section draws on Nil S. Satana, "Transformation in Perspective: Attitudinal and Constitutional Changes in Turkish Civil-Military Relations" (Netherlands: CESS, Greenwood Papers Series, forthcoming). EU civil-military relations framework is the main focus since the convergence of Turkish CMR with the American paradigm is analyzed in Satana, "Transformation of the Turkish Military and the Path to Democracy" (2008).

19. Forster, Armed Forces and Society in Europe (2006); Anne Aldis and Margriet Drent, Common Norms and Good Practices of Civil-Military Relations in the EU, Harmonie Papers 21 (Groningen: CESS, 2008).

20. Peter Volten and Margriet Drent, "Civil Direction of the Military: Redefining the Balance in France, Germany, Romania and UK," in Anne Aldis and Margriet Drent (eds), Common Norms and Good Practices of Civil-Military Relations in the EU, Harmonie Papers 21 (Groningen: CESS, 2008), p. 15. 
21. Wolfgang Wagner, "The Democratic Control of Military Power: Europe," Journal of European Public Policy, Vol. 13, No. 2 (March 2006), pp. 200-216.

22. Peter Volten and Margriet Drent, "Civil Direction of the Military: Redefining the Balance in France, Germany, Romania and UK" (2008), pp. 15-16.

23. While several other criteria can be used to compare Turkey to the European model, these two criteria are preferred in this article since they include several inter-related domains of civil-military relations.

24. Forster, Armed Forces and Society in Europe (2006), p. 25.

25. German Ministry of Defence, White Paper (2006), p. 86. See http://merln.ndu.edu/whitepapers/ Germany_White_Paper_2006.pdf

26. Jos Boonstra, "The Higher Organisation of Defence: A Comparative Overview of Six European States and the Case for an Integrated Defence Organisation," in Sami Faltas and Sander Jansen (eds), Governance and the Military: Perspectives for Change in Turkey, Harmonie Papers 19 (Groningen: CESS, 2006), pp. 110-119.

27. Volten and Drent, "Civil Direction of the Military: Redefining the Balance in France, Germany, Romania and UK” (2008), pp. 30, 38.

28. Satana, "Transformation in Perspective: Attitudinal and Constitutional Changes in Turkish CivilMilitary Relations" (forthcoming).

29. Hans Born, Marina Caparini, Karl W. Haltiner and Jürgen Kuhlmann (eds), Civil Military Relations in Europe (New York: Routledge, 2006), p. 247.

30. Volten and Drent, "Civil Direction of the Military: Redefining the Balance in France, Germany, Romania and UK" (2008), pp. 30, 38.

31. Ibid., p. 31.

32. Boonstra, "The Higher Organisation of Defence: A Comparative Overview of Six European States and the Case for an Integrated Defence Organisation" (2006), p. 113.

33. Official web site of the U.K. Ministry of Defence: http://www.mod.uk/DefenceInternet/AboutDefence/ CorporatePublications/Structure/DepartmentalOrganisationCharts1.htm; How Defence Works: Defence Framework, The UK Ministry of Defence, 2009. See http://www.mod.uk/NR/rdonlyres/ 001123AD-34F2-4CE5-AF07C622A99A4F6C/0/defence_framework_20090630.pdf

34. Forster, Armed Forces and Society in Europe (2006), Chapter 8.

35. The former Chief of the General Staff İlker Başbuğ had started weekly meetings with Prime Minister Recep Tayyip Erdoğan. Current Chief of the General Staff Işık Koşaner has so far continued the same practice of weekly meetings with Erdoğan. See: http://www.milliyet.com.tr/kosaner-le-15-dakika/ siyaset/haberdetayarsiv/15.09.2010/1289228/default.htm

36. The French White Paper on defence and national security resembles the Turkish one in its objectives and institutional mechanism to undertake defense policies. http://www.ambafrance-ca.org/IMG/pdf/ Livre_blanc_Press_kit_english_version.pdf

37. Boonstra, "The Higher Organisation of Defence: A Comparative Overview of Six European States and the Case for an Integrated Defence Organisation" (2006), pp. 122-3.

38. Law on Role and Authority of the Ministry of Defense, dated July 31, 1970 and numbered 1325; Official Gazette, no.13572, August 7, 1970.

39. Satana, "Transformation in Perspective: Attitudinal and Constitutional Changes in Turkish CivilMilitary Relations" (forthcoming).

40. Boonstra, "The Higher Organisation of Defence: A Comparative Overview of Six European States and the Case for an Integrated Defence Organisation" (2006), p. 30.

41. On May 7, 2003, the last Paragraph of the Article 160 of the 1982 Constitution on the exemption of state property in the possession of the Armed Forces in accordance with the principles of secrecy necessitated by national defence from the control of the Court of Audit was repealed. On August 7, 2003, a by-law to establish the principles and procedures to be observed when auditing state property used by the Armed Forces was adopted by the parliament. On December 10, 2004, the Law on Public Management and Control brought extra-budgetary funds into the overall state budget. On December 3, 2010, Law No. 6085 was passed to increase the jurisdiction of the Turkish Court of Accounts. See http://rega.basbakanlik.gov.tr/eskiler/2010/12/20101219-1.htm. 
42. Klaus-Jürgen Müller, ed., The Military in Politics and Society in France and Germany in the Twentieth Century, German Historical Perspectives Series, eds. Gerhard A. Ritter and Anthony J. Nicholls, vol. IX (Oxford: Berg, 1995).

43. Ibid.

44. Stefan Sarvas, "Professional Soldiers and Politics: A Case of Central and Eastern Europe," Armed Forces and Society, Vol. 26, No. 1 (Fall 1999), pp. 99-118.

45. Ibid., p. 101.

46. Ibid., p. 102.

47. Ibid., p. 114.

48. Christopher D. Jones and Natalie Mychajlyszyn, "Overview: Civil-Military Relations in Central and Eastern Europe in Former Communist Societies," Armed Forces and Society, Vol. 28 (Spring 2002), pp. 375-84.

49. Ibid.

50. Zoltan Barany, "Democratic Consolidation and the Military: The East European Experience," Comparative Politics, Vol. 30, No. 1 (October 1997), pp. 21-43.

51. Ibid., pp. 32-3.

52. Ibid., p. 33.

53. David Betz, Civil-Military Relations in Russia and Eastern Europe (London: Routledge, 2004).

54. The CMR literature includes North African countries in the Middle Eastern paradigm; I follow the same tradition.

55. The region attracted scholarly interest until the number of coups declined by the 1970 s. See for a survey of the literature in that period: Dankwart Rustow, The Military in Middle Eastern Society and Politics (Washington, DC: Brookings Institution, 1963); J.C. Hurewitz, Middle East Politics: The Military Dimension (New York: Praeger, 1969); George Haddad, Revolutions and Military Rule in the Middle East (New York: Robert Speller \& Sons, 1971).

56. Majid Khadduri, "The Role of Military in Middle East Politics," The American Political Science Review, Vol. 47, No. 2 (June 1953), p. 523.

57. Ibid.

58. Ibid., p. 511.

59. Ibid., p. 524.

60. Janissaries have resisted modernization and Westernization attempts for decades; however, the military became a modernizing force toward the end of the 19th century. Feroz Ahmad, The Making of Modern Turkey (London: Routledge, 1993), pp. 29-30.

61. Khadduri, "The Role of Military in Middle East Politics" (1953), p. 518.

62. Ibid., p. 517.

63. Ahmad, The Making of Modern Turkey (1993).

64. James A. Bill, "The Military and Modernization in the Middle East," Comparative Politics, Vol. 2, No. 1 (October 1969), p. 54.

65. Ibid., p. 47.

66. Samuel P. Huntington, The Soldier and the State: Theory and Politics of Civil-Military Relations (New York: Vintage Books, 1957), pp. 87-8.

67. Mehran Kamrava, "Military Professionalization and Civil-Military Relations in the Middle East," Political Science Quarterly, Vol. 115, No. 1 (2000), pp. 67-92.

68. David Sorenson, "Civil-Military Relations in North Africa," Middle East Policy, Vol. 14, No. 4 (2007), pp. 99-114.

69. Kamrava, "Military Professionalization and Civil-Military Relations in the Middle East" (2000), p. 68.

70. Barry Rubin, "The Military in Contemporary Middle East Politics," Middle East Review of International Affairs, Vol. 5, No. 1 (March 2001).

71. Rebecca Cann and Constantine Danopoulos, "The Military and Politics in a Theocratic State: Iran as a Case Study," Armed Forces and Society, Vol. 24, No. 2 (Winter 1997), pp. 269-89; Bayram Sinkaya, “İran' da Asker-Siyaset İlişkileri ve Devrim Muhafızları’nın Yükselişi,” Ortadoğu Etüdleri, Vol. 2, No. 2 (January 2010), pp. 115-42. 


\section{N. S. Satana}

72. Cook, Ruling but not Governing (2007).

73. Juan J. Linz and Alfred Stepan, Problems of Democratic Consolidation: Southern Europe, South America, and Post-Communist Europe (Baltimore, MD: Johns Hopkins University Press, 1996).

74. Recently, the Turkish military has been prosecuted for "plotting coups" against the JDP government. Although evidence was controversial for the so-called Ergenekon case, the military has hardly objected to the prosecution process. Lately, a request for trial of the 1980 coup-makers was made and the military has not objected to that either.

75. Recent "revolutions" in the Middle East shows that the role of the military in Middle Eastern countries may change in the future for better or worse.

76. See Metin Heper, "Civil-Military Relations in Turkey: Toward a Liberal Model?" in this volume.

77. Satana, "Transformation of the Turkish Military and the Path to Democracy" (2008).

78. See Metin Heper, "Civil-Military Relations in Turkey: Toward a Liberal Model?" in this volume.

79. See the 2010 Progress Report at: http://ec.europa.eu/enlargement/pdf/key_documents/2010/package/ tr_rapport_2010_en.pdf 